\title{
LRP8 wt Allele
}

National Cancer Institute

\section{Source}

National Cancer Institute. LRP8 wt Allele. NCI Thesaurus. Code C95250.

Human LRP8 wild-type allele is located in the vicinity of $1 \mathrm{p} 34$ and is approximately $83 \mathrm{~kb}$ in length. This allele, which encodes low-density lipoprotein receptor-related protein 8 , is involved in signal transduction, neuronal development, ligand endocytosis and lipid metabolism. Mutation of the gene is associated with myocardial infarction type 1. 